\title{
Tipping for charity: a field experiment in charitable giving on free walking tours
}

\section{Britta Butz $^{1}$ D $\cdot$ Christine Harbring $^{1}$}

Accepted: 31 August 2021 / Published online: 22 October 2021

(C) The Author(s) 2021

\begin{abstract}
The following field experiment analyzes the effect of payments in a setting of shared social responsibility where charitable giving is incorporated into a pay-what-youwant scheme as a share of the payment. The field experiment involved free walking tours. Within a timeframe of 10 weeks, tours operated as usual, while every second week a Donation Week was implemented. During Donation Week, 5\% of the tips were donated to a charitable organization by the tour firm. Results reveal that tips are significantly higher in the Donation Week compared to the Baseline and that the rise in tips roughly outweighs the cost of the donation payment. Thus, while tour guides' profits do not differ between treatments donations to charity may be generated additionally in Donation Week.
\end{abstract}

Keywords Pay-what-you-want - Charitable giving - Shared social responsibility · Corporate social responsibility $\cdot$ Field experiment

JEL Classification C93 · D49 · D64 · H41

\section{Introduction}

Even though research on Corporate Social Responsibility (CSR) in general has been conducted for several decades now, the question remains of whether and, if so, how the versatile activities of CSR contribute to a company's success (see, e.g., Margolis et al. 2009; Wang et al. 2016; Vishwanathan et al. 2019). Nevertheless, research on specific CSR activities, e.g. cause-related-marketing (CRM), in which a product or service is directly connected to charitable giving by the company, reveals results that are quite promising for companies (see, e.g. Strahilevitz and Myers 1998; Moosmayer and Fuljahn 2010; Green and Peloza 2011, Sheikh and Beise-Zee 2011). Therefore, it might not be astonishing that short-term CRM campaigns like "One

Britta Butz

britta.butz@org.rwth-aachen.de

1 RWTH Aachen University, Templergraben 64, 52062 Aachen, Germany 
Pack $=$ One Vaccine" in developing nations of diapers by Procter \& Gamble (Pampers 2020), "Buy one pack of Krombacher beer and save one square meter of rainforest" (Krombacher 2020) or long-term approaches like "AmazonSmile" (Amazon 2020) remain popular for companies.

Gneezy et al. (2010) introduced a related approach called shared social responsibility (SSR), which also seems to be profitable for companies and charitable organizations. In SSR, the idea of connecting a donation payment directly to the purchase of a product or service remains, while the pricing scheme differs from that of CRM. Instead of a fixed price, a pay-what-you-want (PWYW) price setting is used, meaning that the customer decides on the price paid or even pays nothing at all (see, e.g. Kim et al. 2009; Chao et al. 2015). In SSR, the donation is included as a share of the amount paid, and therefore, the customer can directly influence the donation amount. Research on PWYW pricing reveals that most people pay positive amounts, and research indicates that PWYW can be profitable due to rising sales (see, e.g. Isaac et al. 2010; Kim et al. 2010; Riener and Traxler 2012; Chao et al. 2015). Besides Gneezy et al. (2010), further studies indicate positive effects of SSR on buying intention, payment amounts, and companies' profits (Park et al. 2016; Jung et al. 2017). These field studies focused on selling products such as souvenir photos, coffee, or grocery bags. They varied on the one hand whether the product was sold at a fixed price or a PYWY pricing scheme and varied on the other hand whether a donation was included in both price settings. Within these studies the positive effects of implementing SSR are mainly ascribed to preferences of altruism, impure altruism, reciprocity, image concerns, and peer pressure (see, e.g.Andreoni 1989; Harbaugh 1998a, b; Soetevent 2005; Crumpler and Grossman 2008; Jung et al. 2017; Kajackaite and Sliwka 2017).

In contrast to previous studies on SSR, we implement a small relative donation amount of 5\% dependent on the price paid in a PWYW setting in which payments are publicly made for a service of known quality. Following preceding research results we assume that implementing the donation may positively affect customers' payments. Though, customers may also perceive this donation as irrelevant, not authentic simply due to its magnitude which could crowd out the voluntary payments (Dahl and Lavack 1995). Thus, our foremost contribution to the empirical literature on SSR in PWYW settings is to show (i) a positive effect of donations on payments compared to a setting without donations and (ii) that the increase in payments outweighs the cost of the donation.

Moreover, our analysis includes the payment for a service instead of a product. And, payment is done after the service has been fulfilled, meaning that customers know about the quality of the service and how much it is worth to them. Additionally, we are looking at a group setting in which payments are made publicly, and therefore participants might be influenced by the presence of others and the amounts that other participants give. Furthermore, participants were not able to select into the donation setting, as information about the donation payment was given after the service had already started. To conclude our analysis may be able to strengthen earlier findings and make it more appealing for companies to implement a SSR approach even when only small fractions of donations seem feasible. Subsequently, more win-win situations for companies and charitable organizations could be created. For 
our study, we conducted a field experiment with free walking tours in Melbourne (Australia). Free walking tours are guided city tours which are not paid for at a fixed price but on a PWYW payment at the end of a tour. Nowadays, tours are offered in many cities all around the world, and in larger cities several operators are usually established. Operators range from one-person operators to operators employing several tour guides in several cities. Tours usually take around 1-3 h while some "city in a day" tours can take up to $8 \mathrm{~h}$. Normally, participants can register online for a tour or they just show up at the arranged meeting point and time. At the beginning of a tour, the tour guide usually introduces the concept of a free walking tour, which is that people do not need to pay anything at all but that it is appreciated if they "pay what the tour was worth to you". At the end of the tour, tips are typically collected by handing around a bag or a cap, or participants give the money directly to the tour guide.

Within our field experiment, we introduced SSR into free walking tours in Melbourne by varying whether a $5 \%$ donation share was implemented or not. Therefore, tour guides announced in half of the ten observation weeks that $5 \%$ of the tips given at the end of the tour would be donated to a charitable organization. Based on earlier research results and a framework we derive in the next section, we predict a rise in payment amounts through introducing the donation payment. In a nutshell, we assume that the organization may credibly signal, for example, a preference for altruism via implementing a costly donation. Customers with a similar (aspired) preference may positively perceive this "self-congruence" and increase donations. Instead of altruism also other motives may be relevant, e.g. warm glow or peer pressure and image concerns both being fostered by others watching in our particular group setting.

Results reveal a significant increase in average tips in Donation Week compared to Baseline Week. Therefore, the operators earn the same profits in both settings, while donation payments are generated in Donation Week. Thus, we can strengthen the existing results in the literature that show that positive effects occur when including charitable giving into a PWYW pricing scheme. Therefore, introducing donation payments into a PWYW price setting — even when they are small—seems to be a promising avenue for companies' CSR activities.

\section{Related literature and predictions}

We concentrate on two aspects that might be most relevant when deciding whether to include a donation share within a company's PWYW pricing scheme or not. First companies might question whether the donation share will increase the willingness to pay of the customer and, second, whether this increase outweighs or even exceeds the cost of the donation payment. ${ }^{1}$

\footnotetext{
${ }^{1}$ A third component might be the question whether including a donation might increase customer demand. In the following, we do not focus on this aspect as in our study participants had no information about the donation share before deciding to take part in the free walking tour.
} 
Earlier empirical research on PWYW and SSR indicates a positive effect of tying donations to payments. Gneezy et al. (2010) conducted a field experiment in an amusement park, varying the price scheme of souvenir photos that were taken during a roller coaster ride. Their results show that including a donation share (of $50 \%$ ) in a PWYW price scheme increased the willingness to pay significantly compared to a PWYW setting without donation payments. Furthermore, the increased payments exceeded the cost of the donation payment. In total, the setting of SSR was more profitable for the company compared to the PWYW price scheme. Further, Park et al. (2016) analyzed a PWYW setting including charitable giving by implementing different conditions in a coffee shop in South Korea. Their results indicate that the amount paid increases when including a donation share (of 50\%) into a PWYW price scheme. Nevertheless, the cost of the donation payment could not be outweighed. Additionally, Jung et al. (2017) conducted two field studies to examine the effect of SSR when customers can decide on the price to be paid. They sold reusable grocery bags and doughnuts on a PWYW basis in front of a supermarket varying whether a share of payments would go to a charity (shares between 1 and $100 \%$ ) or not. Results reveal that customers who bought a bag paid significantly more when charitable giving was included; the share of donations did not affect payment amounts. Furthermore, the increased payments exceeded the cost of the donation payment up to a donation share of $50 \%$. In these settings, profits were significantly higher compared to a PYWY setting without donation payments.

There are a variety of potential mechanisms that might particularly enhance the positive effects of SSR on payments. Two candidates-altruism and impure altruism-are quite often mentioned in the context of charitable giving. As donations are tied to a PWYW setting customers can directly influence donation amounts. Furthermore, impure altruism, the so-called "warm glow", is said to generate positive feelings from the act of giving itself (Andreoni 1989; Crumpler and Grossman 2008). Jung et al. (2017) indicate that impure altruism might be an important driver in SSR settings, since varying the donation share did not influence payment amounts. Therefore, the act of donating itself might drive higher payments compared to a setting in which no donations are made. Finally, also reciprocity, image concerns and peer pressure are likely to affect giving donations.

In the following, we build a framework for the predictions in our setting by bundling literature from the field of customer research, the economic as well as psychological perspective on motives for charitable donations. We start with an analysis of the seller. Tying the donation share directly to the PWYW pricing scheme indicates that the seller is willing to sacrifice her or his own revenues to the donation payment, as a share of revenues is given to charity. These costly donations might credibly signal to the customer that the seller has strong altruistic preferences. In contrast, a setting in which the seller uses a PWYW setting and collects donations separately might not send out such a strong signal, as there are no obvious costs for the seller. Also, research indicates that a signal of prosocial behavior is more effective when it comes with personal cost (see, e.g. Bénabou and Tirole 2004; Gneezy et al. 2012). Within SSR, these personal costs are given for the seller and, therefore, customers might positively reciprocate towards these altruistic preferences by paying higher amounts. 
Zogaj et al. (2021) provide an interesting framework based on consumer psychology research to structure customer behavior which we apply to our specific setting in the following. They indicate that donors' behavior may be influenced by how much each person's image of her-/himself, i.e., the self-concept, matches the self-concept of another individual or entity. They differentiate between the actual self-congruence when someone compares her/his actual self to others and the ideal self-congruence when one compares her/his ideal self-concept to the other concept. A higher degree of similarity between the concepts may induce a stronger feeling of consistency and may strengthen the relationship between the self and the respective other. Applying this framework to our setting we may assume that the perception of an altruistic organization may induce individuals with a taste for altruism to donate due to actual self-congruence while individuals who strive for altruism as an ideal may do so for ideal self-congruence.

Though, recent research also shows that the motives to donate to charity may be manifold (e.g. Ottoni-Wilhelm 2017; Konrath and Handy 2018). In Konrath and Handy (2018) a scale is developed to differentiate these motives better. Based on this strand of research we may assume that altruism may just be one possible motive for donations here (for the organization as well as the individual customers). Altruism is denoted as a "public benefit" as it also refers to others; the remaining public benefits may be that individuals donate for social reasons as one strives for aligning behavior with family and friends and due to trust in the charitable organization. In addition to the public benefits there are "private benefits" from donations referring to an increased benefit only for oneself. ${ }^{2}$ Individuals may donate for private reasons when they aim at avoiding a groups' disapproval or peer pressure (being a social motive) and increasing their own reputation or prestige as a donor. Prestige might be received when acting in line with social norms, and peer pressure arises from the fear of being shown social disapproval from others when not meeting social norms. The charitable giving literature indicates positive effects on donation amounts when donations are made publicly (e.g. Harbaugh 1998a; b; Soetevent 2005; Alpizar et al. 2008; Ariely et al. 2009; Reyniers and Bhalla 2013). The empirical evidence supports the argumentation that higher donation amounts are influenced by feelings of peer pressure and image concerns.

Moreover, a private benefit may be that negative feelings of guilt are reduced via donating or the benefit may stem from reciprocity towards others. Finally, individuals may gain utility from the act of donating itself, i.e. warm glow or impure altruism (see also Andreoni 1989; Crumpler and Grossman 2008).

Thus, the seller may signal the relevance of one of those motives (described above) for donations by tying the donations to the tips and customers' payments may positively be affected because of the desire for actual or ideal self-congruence. Zogaj et al. (2021) also outline that self-congruence may be subconsciously formed and affects functional congruence subsequently, i.e. the perceived similarity of expected product characteristics with its realization. This may even further enhance

\footnotetext{
2 This is in line with the dual-motive theory (see Ottoni-Wilhelm 2017) according to which charitable giving may be due to altruism or egoism/warm glow both of which can be differentiated even further.
} 
the positive effect in a PWYW-setting as functional congruence should also positively affect the willingness to pay for the service or product.

Following previous research and the preceding rationale, we predict a positive effect of including $5 \%$ of tips being donated on the willingness to pay at the end of free walking tours. Our group setting with individuals donating visibly for others might particularly foster concerns of peer pressure and image concerns. The group setting might also enable participants to observe others' payments and to identify what behavior is socially accepted (Martin and Randal 2008; Croson et al. 2009; Shang and Croson 2009; Smith et al. 2015). Further, we predict that increased payments may outweigh or even exceed the cost of our 5\% donation payment, as Jung et al. (2017) and Gneezy et al. (2010) show profitability with donation amounts of up to $50 \%$ of the payment.

\section{Experimental design}

To answer our research question, we conducted a field experiment based on the initial research idea, we collected data with a free-walking-tour operator. We ran two different treatments over a period of 10 weeks. Tours operated as usual for 5 weeks during that period (Baseline Week), while a 5\% donation was implemented for the other 5 weeks (Donation Week). The Baseline and the Donation Week alternated each week during the data collection period.

The field experimental data were collected in cooperation with a company running free walking tours in Melbourne (research inquiry see Appendix A. 1). The research design had to be developed in cooperation with the company, as we had to consider the existing policies and procedures of the company's operations. In total, we were able to collect data from 301 tours. Data collection started on September 23, 2019 and ended on December 1, 2019.

During the data collection period, three tours were operated daily. Two tours (one in the morning and one in the afternoon) focused on general sights of Melbourne, taking around $2 \frac{1}{2}$ to $3 \mathrm{~h}$. Additionally, one tour focused specifically on Melbourne's culture and ran in the evening, taking around $1 \frac{1 / 2}{\mathrm{~h}}{ }^{3}$ For each tour, at least two guides were scheduled. Depending on the group size, they would split it up into two or more groups. The company employed 11 tour guides during the data collection period. To capture the relevant data, each tour guide had to fill out a basic information survey. The tour guides were asked for their gender, age, and experience with conducting free walking tours, as we consider these to be relevant control variables (see Appendix A. 2).

Furthermore, the tour guides had to fill out an additional survey after each tour. The company was already using a reporting sheet to capture data for their own records (see Appendix A. 3). Most importantly for our investigation, the survey

\footnotetext{
${ }^{3}$ Note that in the first week of data collection, this tour was running in the afternoon instead of the evening. We included a control variable in the analysis for the different times.
} 
included questions about the amount of money involved in tips and the number of participants at the beginning and the end of the tour. Please note that we could not capture individual tips given. Therefore, we used the average tips provided by the participants that stayed until the end of the tour as our dependent variable. The reporting sheet included the tour guide's name, the date of the tour, as well as the tour name and time. Furthermore, the sheet captured whether the tour guide was required to do that particular tour. ${ }^{4}$ These data were also used to capture the average number of tours that each tour guide was doing per week. Doing a large number of tours per week could, on the one hand, lead to a better performance but, on the other hand, might result in boredom and an inferior performance. Additionally, the weather conditions were captured. For our research request, additional questions were included. First, we asked whether the tour guide had stated that $5 \%$ of tips would go to charity. With this procedure we controlled whether the guides had followed the planned schedule or had mistakenly used a wrong procedure. Furthermore, we tried to capture the quality of each tour and the satisfaction of the tour participants, as we consider both to be important drivers of the amount of money involved in tips given by the participants. It was not possible to capture feedback directly from the tour participants, since earlier attempts had delivered very few responses from tour participants to the appeal to fill out a survey. Additionally, we explored whether we could capture satisfaction via online ratings like Google Review or TripAdvisor. On average, the company received one to two reviews per week on these platforms. Subsequently, it was not possible to derive the participants' satisfaction from these platforms for each tour. Therefore, we decided to include two control questions in the tour guides' survey which asked for the tour guides' perception of their own performance (7-Likert scale ranging from very poor to very good) and the perceived satisfaction of the tour participants (7-Likert scale ranging from very dissatisfied to very satisfied). Of course, these are quite insufficient measures as they are only reflect the guides' self-perception and may correlate with tips received. Additionally, we used the percentage of people who had dropped out during the tour as a proxy for the quality of the tour.

Tour guides were primarily informed about the project and the procedure via e-mail (see Appendix A. 4) by the operation managers of the company. Tour guides were actively included in the feedback process of the project and in the decision about the charitable organization. Further, they were informed about the duration of the project and that donations would be announced and made only every second week during that period. In addition, tour guides received information about how and when the information about the donation should be fitted into the tour. Tour managers also stated that the way in which the tour guides informed participants about the donation should be non-demanding. Additionally, the tour operators forwarded some important requirements from our side. It was very important that all guides should introduce the donation concept at the same stage of a tour and in the same manner. Furthermore, no other changes to the usual tour procedure or to what was said during the tour should be made within the 10 -week period of data

\footnotetext{
${ }^{4}$ Depending on the group size, they would split it up into two or more groups. Therefore, several guides were scheduled but not always needed to do a tour.
} 
collection. Tour guides should also not inform the participants about the research project. Moreover, we recommended telling participants - should they enquire-that the donation payments were a newly implemented concept and that further information about the charity could be found on the charity's website. Furthermore, if participants demanded proof of their donation, participants were asked to send an e-mail to the tour operators in order to obtain a receipt of the donation payment (this actually never happened).

Donation payments were given to Launch Housing in Melbourne, which is an independent community agency striving to end homelessness in Melbourne (see https://www.launchhousing.org.au/). The free walking team decided in favor of this organization, as all of them could identify with the mission of this charity. Furthermore, homelessness is an obvious problem in Melbourne which participants will recognize during the tour. Therefore, it was possible to integrate the aim of the charitable donations nicely into the free walking tour. Further, the operators decided on a donation amount of $5 \%$ of the total tips.

The company decided to mention the donation payment twice during a respective tour: first, at the beginning after the introduction of the "Free Walking Tour" concept and, second, in the middle of the tour. Donations would not be mentioned at the end of the tour; as it might seem too "obvious" and "demanding" to mention them just before tips were going to be given. The tour operators actively considered how to implement the donation payment within the flow of the tour and in line with the values of their company. The following text was chosen to introduce donation payments during the Donation Week at the beginning of a tour:

'As well as having no paid advertising on our tours, 5\% of all our tips are given to Launch Housing, a local charity chosen by our guides that works to eliminate homelessness in Melbourne. As we take you all through Melbourne, we want to help you all feel part of the local community and for us, part of that is about giving back to our city.'

In the middle of the tour (at a specific stop in the tour) tour guides mentioned it in the following way:

'Now it's possible you've noticed a few homeless people around the city on the tour so far. In Victoria, homelessness affects about 1 in every 240 people (around 25,000 in total). The reasons for this vary from things like drug and alcohol addiction to a shortage of affordable housing around Melbourne. One problem that makes this worse is that you need to have a fixed address to be eligible to receive government support and to do other simple things like be able to vote. What that means is that some of the most vulnerable people in Melbourne who need the most help aren't able to access it, and also aren't able to vote to change that. As guides we are incredibly proud of the city we live in and we love showing it off to all of you, but we also appreciate that Melbourne is far from perfect.

This is why we've decided to give 5\% of all tips received to a charity called Launch Housing and rather than hiding the confronting side of the city from you, we want to be part of making our local community a better place. By giving people 
a roof over their heads, Launch are able to put people in a position where they can then access more assistance and start to get their lives back on track.'

During the Baseline Week, tour guides left out the introduction of the donation at the beginning. They still mentioned the first paragraph in the middle of the tour, while leaving out the last paragraph mentioning the donation payment.

\section{Results}

\subsection{Descriptive and nonparametric statistics}

As mentioned above, we were able to collect data from 301 tours. Observations had to be discarded if tour guides followed the wrong procedure, e.g. if they forgot to talk about the donation in Donation Week or when donations were to be mentioned in Baseline Week. Tour guides indicated any mistakes that they recognized in the "comment" field of their survey. In total, we can use 275 tour data sets involving a total of 6628 participants for our data analysis. ${ }^{5}$ Data include 143 tours from Donation Week and 132 tours from Baseline Week. Table 1 gives an overview of all tour guides. From eleven tour guides, four are female and seven are male. The average age is 25 years and guides had already operated an average of 21 months as a tour guide when data collection started. The number of tours undertaken within our data collection time varies between 3 and 43 tours with an average of 26 tours per guide.

In our analysis, the dependent variable is the average tips given by the participants at the end of a tour. The average was calculated by dividing the total amount of money involved in tips by the number of participants who stayed until the end of a tour. We will use the ratio between the number of participants who stayed until the end of a tour and the number of participants showing up at the beginning of a tour as a control variable in our regression analysis. Note that we were not able to collect data on the individual tip level.

Figure 1 illustrates the distribution of average tips per week for all tours. The average tip per tour varies considerably and lies between 8.68 and 14.56 AUD in the Baseline Week in comparison to between 8.87 and 14.97 AUD in the Donation Week. In the following, we will focus on analyzing our data on the tour guide level, as average tips vary significantly between tour guides in the Baseline Week (see Appendix A. 5 for pairwise comparison of average tips in Baseline Week between guides).

Table 2 shows the average tips per guide split into the Baseline Week and Donation Week. Using a Wilcoxon matched-pairs signed-ranks test, we check for differences between treatments per guide. Results reveal a weakly significant positive effect for average tips in the Donation Week compared to the Baseline Week $(p=0.0593)$. Taking a look at each guide separately, we find higher average tips in the donation intervention for 8 guides and lower average tips for 2 guides. Note that guide 4 did not run any tours in Baseline Week. The increase of average tips during

\footnotetext{
5 In total, 7118 participants showed up for a free walking tour and a total of 6629 participants stayed until the end of a tour.
} 


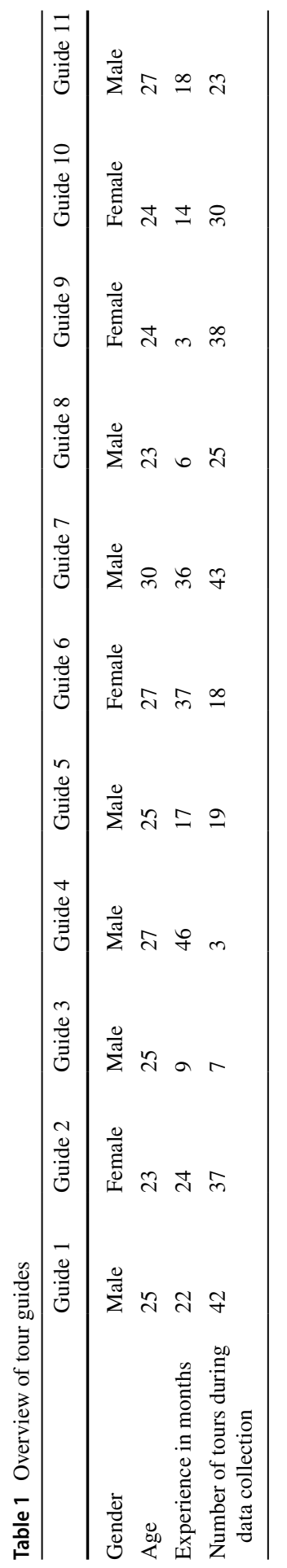




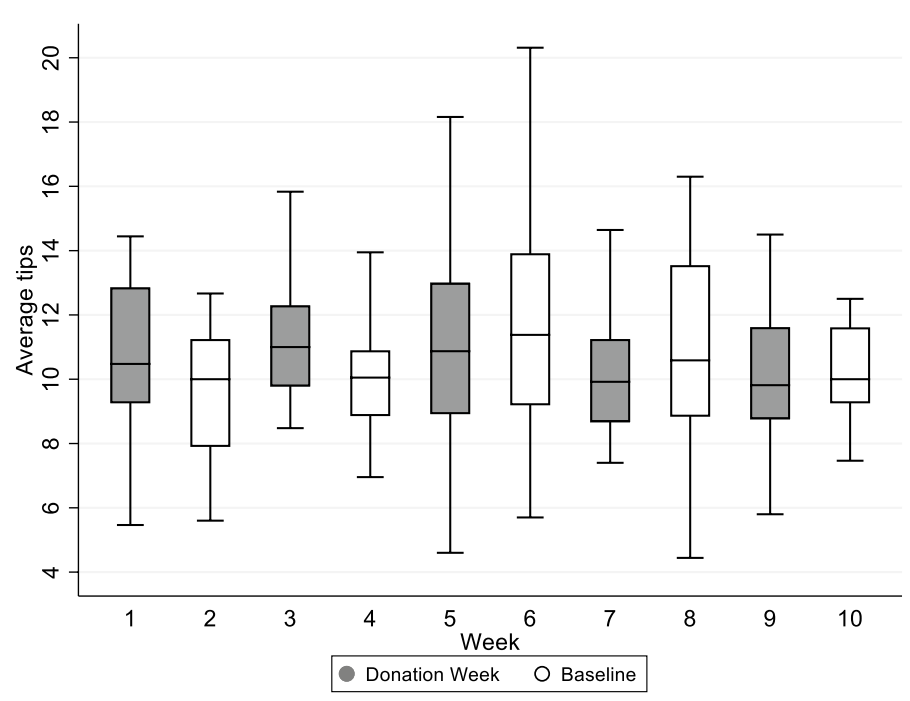

Fig. 1 Boxplot of average tips per tour

Donation Week ranges from 0.01 to 1.33 AUD (0.11-13.03\%) and reductions are between 0.32 and 0.48 AUD (2.84-4.53\%). Among the guides achieving positive effects, donation payments are refinanced by $2.27-229.31 \%$ through the increased tips given.

\subsection{Regression analysis}

Table 3 displays the regression analysis for average tips per tour. All models include the Donation Week dummy variable as well as the observation week number. Further, we include dummies for each guide excluding guide one as a reference in each model. Including the dummy variables for the guides is especially important as average tips differ significantly between guides in Baseline Week (see Appendix A. 5 for pairwise comparison of average tips in Baseline Week between guides). We excluded guide 4 completely from the regression models as no data could be collected for the Baseline Week. Model II adds whether the tour was a sights tour (dummy sights =1) or a cultural tour (dummy sights $=0$ ). Model III additionally includes the ratio of the number of participants who stayed until the end of a tour and the number that showed up at the beginning of a tour. The lower the ratio, the more participants left a tour before it was finished. In Model IV, we included how satisfied tour guides thought participants were and how they would rate their own performance. The scale reached from one (very dissatisfied) to seven (very satisfied). Model V includes further control variables, like the time of day when the tour took place, the temperature, and the weather (See Appendix A. 6 for the full regression including all controls.). The morning dummy as well as the sunny dummy were excluded as a reference. ${ }^{6}$

\footnotetext{
${ }^{6}$ Reference groups always had the highest number of observations.
} 


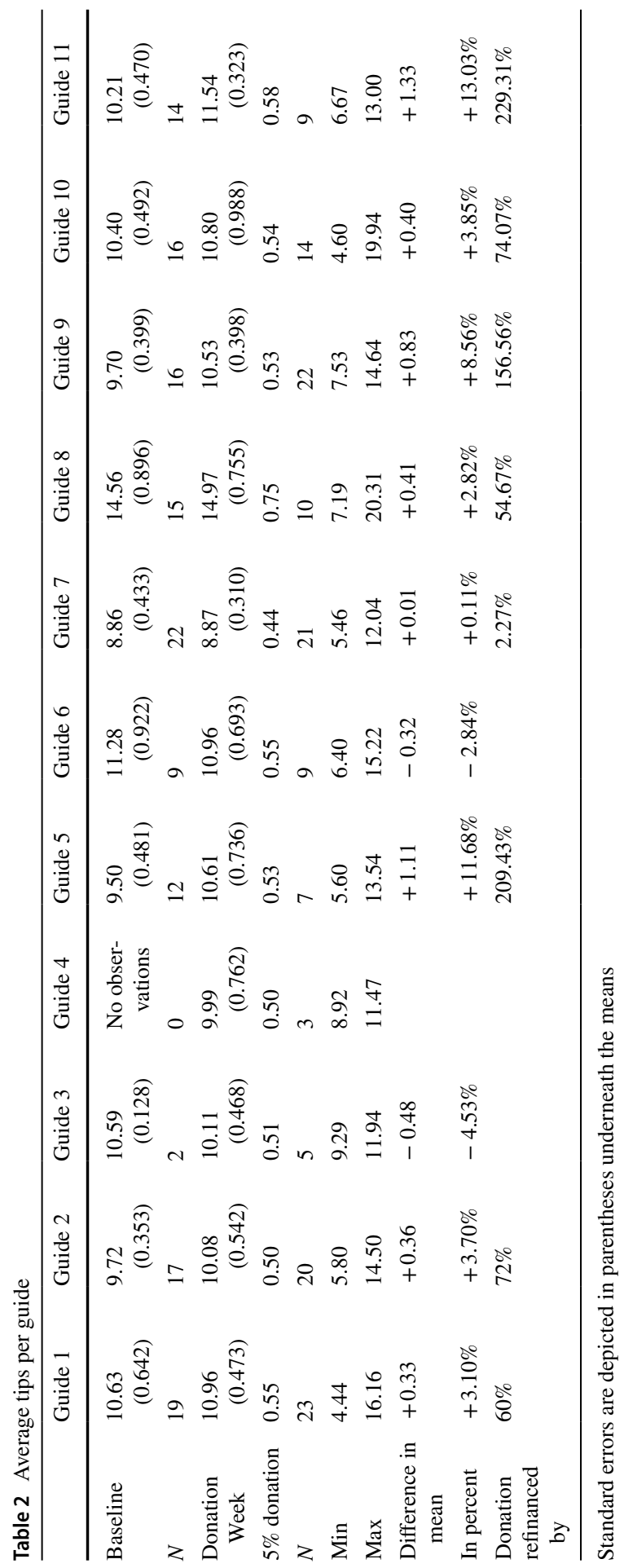


Table 3 OLS regression on average tips per tour

\begin{tabular}{|c|c|c|c|c|c|}
\hline VARIABLES & Model I & Model II & Model III & Model IV & Model V \\
\hline $\begin{array}{l}\text { Dummy donation week } \\
\text { (1=yes) }\end{array}$ & $\begin{array}{r}0.482 * * \\
(0.153)\end{array}$ & $\begin{array}{l}0.510 * * \\
(0.169)\end{array}$ & $\begin{array}{l}0.482 * * \\
\quad(0.181)\end{array}$ & $\begin{array}{r}0.512 * * * \\
(0.135)\end{array}$ & $\begin{array}{r}0.580 * * * \\
(0.158)\end{array}$ \\
\hline Dummies guides & INDLUDED & INDLUDED & INDLUDED & INDLUDED & INDLUDED \\
\hline Dummy Sights & & $\begin{array}{r}2.046^{* * * *} \\
(0.409)\end{array}$ & $\begin{array}{r}1.886 * * * \\
(0.431)\end{array}$ & $\begin{array}{r}1.694 * * * \\
(0.445)\end{array}$ & $\begin{array}{l}1.174 \\
\quad(1.002)\end{array}$ \\
\hline $\begin{array}{l}\text { Number of participants } \\
\text { end-start-ratio }\end{array}$ & & & $\begin{array}{r}-4.149 \\
(2.908)\end{array}$ & $\begin{array}{r}-4.660 * \\
(2.463)\end{array}$ & $\begin{array}{c}-5.558 * * \\
(2.398)\end{array}$ \\
\hline Satisfaction & & & & $\begin{array}{l}0.407 \\
\quad(0.237)\end{array}$ & $\begin{array}{l}0.373 \\
\quad(0.257)\end{array}$ \\
\hline Performance & & & & $\begin{array}{l}0.457 \\
(0.252)\end{array}$ & $\begin{array}{l}0.431 \\
\quad(0.252)\end{array}$ \\
\hline Controls & & & & & INCLUDED \\
\hline Week & $\begin{array}{l}0.0163 \\
\quad(0.0524)\end{array}$ & $\begin{array}{r}-0.00958 \\
(0.0485)\end{array}$ & $\begin{array}{r}-0.00824 \\
(0.0493)\end{array}$ & $\begin{array}{l}0.0145 \\
\quad(0.0302)\end{array}$ & $\begin{array}{l}0.00941 \\
\quad(0.0188)\end{array}$ \\
\hline Constant & $\begin{array}{r}10.47 * * * \\
(0.310)\end{array}$ & $\begin{array}{r}9.072 * * * \\
(0.419)\end{array}$ & $\begin{array}{r}13.06 * * * \\
(3.042)\end{array}$ & $\begin{array}{l}8.499 * * \\
\quad(3.119)\end{array}$ & $\begin{array}{r}9.969 * * \\
(3.717)\end{array}$ \\
\hline Observations & 272 & 272 & 272 & 272 & 272 \\
\hline R-squared & 0.318 & 0.413 & 0.430 & 0.496 & 0.518 \\
\hline
\end{tabular}

$* * * \mathrm{p}<0.01, * * \mathrm{p}<0.05, * \mathrm{p}<0.1$

All models reveal a significant positive effect of the donation week for average tips given per tour. In Donation Week, participants gave a 58 cents higher tip per person in comparison to the Baseline (see Model V). Tour guides' results show average tips in comparison to Guide 1, who received average tips of 10.80 AUD. Models II-IV reveal that the amount of tips given on the sights tour is significantly higher compared to the tips given on the cultural tour. Note that the sights tour took around $2 \frac{1}{2}$ to $3 \mathrm{~h}$ in comparison to $1 \frac{1 / 2}{h}$ for the cultural tour. The ratio of the number of participants who stayed until the end of a tour and participants showing up at the beginning of a tour reveals a significant negative effect in Models IV and V. This indicates that average tips increase, the more people leave a tour before the end. Note that we used the number of participants at the end of a tour to calculate the average tips given and that in four cases, the number of participants at the end of the tour exceeded the number of participants at the beginning of the tour. We do not find any significant effects of the other performance measures. Within the control variables, we find significantly lower tips for tours taking place in the afternoon in comparison to the tours that took place in the morning. Further, we find no significant effect of the week number of the experiment. ${ }^{7}$

\footnotetext{
7 We also ran regressions calculating the average tips given by including those participants that left the tour before it was finished. Main results are robust from Model III onwards.
} 


\section{Summary and discussion}

Within our non-parametric statistic, we find first indications of the positive effects of the $5 \%$ donation on the amount of money involved in tips at the end of the tour. Including all guides, this tendency is weakly significant between treatments and donations increase average tips by $3.95 \% .^{8}$ Our regression analysis confirms our first findings of the non-parametric statistic indicating that average tips rise by 0.583 AUD in Donation Week compared to the Baseline Week.

\subsection{Profits}

To compare the tour guides' earnings between the two treatments we deduct the donation of 5\% from the tips given in Donation Week. Using a Wilcoxon matchedpairs signed-ranks test, we check for differences between average tips received in Baseline Week and average (net) tips received in Donation Week. Results reveal no significant difference $(p=0.3863)$. Thus, they indicate that the earnings between both settings do not differ, while additional donation payments are generated as an extra during Donation Week. Therefore, the use of SSR might be beneficial for the operator in such a setting, as tour guides' earnings are not affected, but donations to charities may be financed via customers' giving.

Please note that the donation payment was not announced ex ante; participants only learned about it during the tour. Thus, the positive effects may rather represent a lower bound of effects, as profits may further increase due to subjects who are particularly prone to donating and who select services with a charitable purpose. ${ }^{9}$ Even though SSR seems to be very attractive for companies to adopt, as donations are only made when revenues occur, they should still be cautious when implementing SSR. As indicated in the CRM literature, it may, for example, be crucial to take care of a brand-cause fit to generate positive effects (Pracejus and Olsen 2004; Nan and Heo 2007; Sheikh and Beise-Zee 2011; Bigné-Alcañiz et al. 2012; Chéron et al. 2012). In our design we considered several circumstances when including SSR in the free walking tours. First, the tour guide decided on the charitable organization, making sure that all guides were aligned with the cause. Second, there was a clear fit between the tour and the cause of supporting homeless people, as this was a visible problem in Melbourne and could be recognized by the participants during the tour. Third, donations were introduced in a non-demanding manner by also not mentioning them right before tips were given. Additionally, participants could demand a contribution receipt, which would have increased credibility. Even though all these actions were taken, effects still vary considerably among the tour guides. However, the operators in our study might have been able to authentically include SSR in most of their tours, which might have supported the overall positive impact of the

\footnotetext{
8 Average of increase "in percent" (see Table 2) for 10 guides.

9 During data collection one participant mentioned the donation payment in a tripAdvisor review that might had been seen by future participants.
} 
donation payments on tips. Moreover, companies should be aware of possible negative consequences, since customers might oppose the chosen cause or the partnered NGO might be involved in bad practices (Sheikh and Beise-Zee 2011).

Important factors for driving the results may be altruism, warm glow, reciprocity, image concerns, and peer pressure (e.g. Jung et al. 2017). Participants of the tours made their payments publicly in a group setting, which may particularly induce participants with image concerns to contribute. Those with image concerns and a social preference may react more strongly in the donation setting. Moreover, following our framework participants' willingness to pay may have been enhanced by the congruent motives for donations signaled by the seller and the customers themselves.

\section{Limitations}

When describing our experimental design, we already mentioned that we were not able to collect data at an individual level. The common process in freewalking tours is that tips are collectively gathered after the tour and tracing each amount back to an individual participant is unfortunately not feasible. Though, individual payments-linked to demographical information-would have given us the chance to investigate the driver of our results more precisely and to control for relevant factors. Furthermore, due to the nature of our field experiment our data is unbalanced as each tour guide ran a different numbers of tours.

Additionally, our performance measures ${ }^{10}$ for which we controlled have some weaknesses. First, the performance measure that was collected from the tour guides might be biased by the knowledge of how much money they have received and the way each guide tends to self-evaluate. Second, using the percentage of people who had dropped out during the tour as a proxy for the quality of the tour might be biased due to other reasons for dropping out, e.g. people might also not be willing or able to give tips at the end of the tour and might try to avoid an uncomfortable situation by leaving the tour beforehand. Third, we did not collect a performance measure directly from participants as this is not a typical procedure after freewalking tours and the organization was not in favor of implementing it. A previous attempt to ask for individual perceptions was not successful as participants were unwilling to give feedback.

As stated above, the donation payment was not mentioned ex ante. Therefore, we could exclude the danger of a selection bias, meaning that participants with strong social preferences might be more attracted to a free walking tour involving a donation share. Nevertheless, participants had the option to opt out of the tour, as they were free to leave the tour at any time. Our data does not indicate that participants left the tour due to the donation payment.

\footnotetext{
10 As mentioned above, we decided to include two control questions in the tour guides' survey which asked for the tour guides' perception of their own performance (7-Likert scale ranging from very poor to very good) and the perceived satisfaction of the tour participants (7-Likert scale ranging from very dissatisfied to very satisfied).
} 
Due to the weaknesses of an experimental design and considering that we focused on one specific service environment further research should be conducted varying the type of service, the country of data collection, or the consumer group. For example, free walking tours might especially provide a service for younger people as the concept was born to provide guided tours for lower income people. Earlier findings indicate a positive effect of age on charitable giving (List 2004; Eckel et al. 2005; Alpizar et al. 2008). Future research might therefore address settings including a larger degree of older and higher income customers.

\section{Outlook}

Avenues for future research could first be the analysis of the effect of group size on the willingness to donate in such a setting where donations are given publicly. Our results indicate that tips increase significantly, the higher the number of people leaving during the tour. Participants might try to outweigh the loss of tips from people not staying until the end of the tour and by increasing their own tips. On the other hand, the effects of image concerns and peer pressure might vary with a changing group size (see for related investigations, e.g. Conlin et al. 2003; Alpizar et al. 2008; Scharf and Smith 2016; Eriksson et al. 2017; Jung et al. 2017).

Another question is whether the size of the donation share may have an effect on payments. Although Jung et al. (2017) indicate that the willingness to buy and pay is not sensitive toward the amount of the donation within SSR, conducting social activities with a low contribution from the company might also be perceived as non-authentic and might result in negative effects (see, e.g. in CRM settings Dahl and Lavack 1995). And, research in CRM indicates stronger positive effects when increasing the donation amount (e.g. Holmes and Kilbane 1993; Strahilevitz 1999; Moosmayer and Fuljahn 2010).

Future research might also address an even stronger integration of the customer. While in SSR settings the customers already influence the donation amount, it might also be interesting to increase their involvement. In CRM there are first approaches of CRM with choice, meaning that the customer can actively choose the cause that the donation is made to (Robinson et al. 2012).

Additionally, more controlled approaches using laboratory experiments should be considered to replicate the study and to investigate the underlying mechanisms. Thereby it might be possible to investigate and control for personal characteristics and social preferences of the service provider as well as the service users.

To conclude, with our study we contribute to the existing literature on SSR by strengthening the findings on the positive effects of incorporating a donation share into a PWYW pricing scheme. Our results indicate that SSR also works in a service environment with frontline workers who introduce a small donation payment in a group setting; applications in similar settings from, for instance, the entertainment or the education business, are perceivable. Possibly, additional positive effects like e.g. an increased demand (see, e.g. Gneezy et al. 2010; Jung et al. 2017), which were not investigated in our study might occur if additional 
advertising of the donation payment takes place. To conclude: SSR might be a stable and promising win-win CSR approach that involves positive effects for companies as well as for charitable organizations.

\section{Appendix}

\section{A. 1: Research inquiry letter}

\section{Subject: Research Project Cooperation Proposal}

Dear Sir or Madam,

My name is and I work as a research assistant with the For the next three months I will be joining the University of Sydney for a research project. Within the scope of my doctoral thesis work, I am focused on the question of whether a collective donation can induce a better team performance.

During a stay in London I came across a new research idea when I took part in a free walking tour there. That is why I am currently seeking a research partner to conduct this research project with me. One special feature of free walking tours is the "Pay What You Want" concept. Previous research has already concentrated on several factors that influence payment in these settings, e.g. reference prices.

My interest is to analyze whether a donation share $(10 \%, 20 \% \ldots)$ might influence the payments from the participants of a free walking tour. The idea would be to inform the participants at the beginning of the tour that a share of their payments will be given to a local non-profit organization - a promise that will definitely be realized. One possible result might be that the willingness-to-pay increases and that the donation might be even compensated due to higher payments. Previous research indicates that even a donation share of $50 \%$ might be more profitable than not including a donation scheme at all (Gneezy et al. 2010).

It would be desirable to find a positive effect of the donation on participants' willingness-to-pay. Simultaneously, it would have the positive side effect of your company supporting a non-profit organization without endangering your financial security. A cooperation with a non-profit organization might also strengthen your company's reputation.

I would be very pleased if we could personally discuss a possible cooperation and I look forward to hearing from you in the near future.

Please let me know if you have any questions in advance.

Best regards, 


\title{
A. 2: Basic tour guide data
}

\section{Basic Data Tour Guides}

The data collection and evaluation takes place according to the Data protection regulations.

1. Your Name

[Please choose]

2. Gender

male $\quad \begin{gathered}\bigcirc \\ \text { female }\end{gathered}$

\begin{abstract}
3. How old are you?
[Please choose]
\end{abstract}

4. How long have you been working as a tour guide?

(months)

5. Do you have any further comments?

Thanks a lot for your participation. 


\section{A. 3: Tour survey ${ }^{11}$}

\section{Melbourne Tour Report 19-20}

Fill in your tour details to report today's tour.

* Erforderlich

Your Name *

Auswählen

Would you like an email of this report? (Type email here)

Meine Antwort

Date of Tour: *

Datum

tt.mm.jjjj

Which Tour *

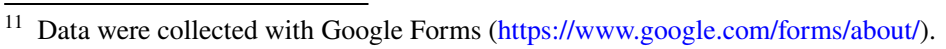




\section{Were You Needed?}

Which Guide *

1st Guide

2nd Guide

3rd Guide

4th Guide

5th Guide

Sonstiges:

Were you needed to tour today? *

Yes

No

\section{Tour Report}

Number of People (START): *

Please include children less than teenager age as 0.5 .

\section{Meine Antwort}

Number of People (FINISH): *

\section{Meine Antwort}

Total Tips *

Meine Antwort 
What was the weather like at the start of the tour? *

Sunny

Cloudy

Drizzly

Raining

Storm

Did you say $5 \%$ of tips will go to charity?

Yes

No

How do you rate the satisfaction of the participants regarding the tour?

$\begin{array}{llllllllll} & 1 & 2 & 3 & 4 & 5 & 6 & 7 & \\ \text { very dissatisfied } & \bigcirc & \bigcirc & \bigcirc & \bigcirc & \bigcirc & \bigcirc & \bigcirc & \text { very satisfied }\end{array}$

How do you rate your own performance?

$\begin{array}{lllllllll} & 1 & 2 & 3 & 4 & 5 & 6 & 7 & \\ \text { very poor } & \bigcirc & \bigcirc & \bigcirc & \bigcirc & \bigcirc & \bigcirc & \bigcirc & \text { very good }\end{array}$

\section{Notes:}

Notable happenings on the tour. Ways people found out about the tour. Anything that would be helpful for other guides! Also if there were any incidents on the tour, please document them here and contact us separately as soon as possible.

\section{Meine Antwort}

ZURÜCK 


\section{A. 4: Information given to tour guides}

Hi Guides,

Thanks for your feedback and passion. It's great to have you all so involved and excited for this trial/experiment for the next 10 weeks.

It will start on Monday the 23rd of September and conclude on Sunday the 1st of December 2019. It will also be every second week you'll mention the charity and I'll note this in 'When I Work'. It's also included in the spreadsheet below. It's to be mentioned on both the CC tour and MS tours.

As I'm sure you can all gather, it's really important that we learn and perform the text properly in order for this to be an accurate trial.

NAME has put together text to be added to your spiel. We'd like it to be spoken about twice. Once at the start when you're introducing yourselves, tour concept and local motto. NAME has found a good way to tie it into our motto (no kickbacks) as well. For the moment we'd also like it spoken about on Bourke St.

Start of the tour (after talking about tips):

'As well as having no paid advertising on our tours, 5\% of all our tips are given to Launch Housing, a local charity chosen by our guides that works to eliminate homelessness in Melbourne. As we take you all through Melbourne, we want to help you all feel part of the local community and for us, part of that is about giving back to our city.'

Bourke St Stop -

'Now it's possible you've noticed a few homeless people around the city on the tour so far. In Victoria, homelessness affects about 1 in every 240 people (around 25,000 in total). The reasons for this vary from things like drug and alcohol addiction to a shortage of affordable housing around Melbourne. One problem that makes this worse is that you need to have a fixed address to be eligible to receive government support, and do other simple things like be able to vote. What that means is that some of the most vulnerable people in Melbourne who need the most help aren't able to access it, and also aren't able to vote to change that.

As guides we are incredibly proud of the city we live in and we love showing it off to all of you, but we also appreciate that Melbourne is far from perfect. This is why we've decided to give 5\% of all tips received to a charity called 
Launch Housing and rather than hiding the confronting side of the city from you, we want to be part of making our local community a better place. By giving people a roof over their heads, Launch are able to put people in a position where they can then access more assistance and start to get their lives back on track.'

As always we want it to be natural and not preachy, similarly when we mention that the tours work on 'tips'. We've also decided not to say it at the end as we don't want to be too pushy.

The research project is done by she's from Germany and working on her PHD at Sydney University so we'll edit the data. She has asked me to pass on this:

- All Tour guides should introduce the donation at the same time and in the same way during the tour

- If they'd like a receipt for the donation we can send this via email

- Please do not change any other procedure of the tour during the 10 weeks of data collection

- Please do not tell the participants about the research project

- If participants, ask about the donation:

o Explain that it is a new concept

p Refer to charity website

To help ___ collect the data NAME will also edit your reporting sheet to help collect and evaluate data. You will notice changes to your reporting sheet in a few days but it won't become mandatory to fill out until the 23rd of September. 


\begin{tabular}{|c|c|c|c|c|c|c|}
\hline & \begin{tabular}{|l|l|} 
क \\
\end{tabular} & $-\infty$ & \begin{tabular}{l|l}
$\infty$ & \multicolumn{5}{c}{.}
\end{tabular} & & & \\
\hline & ஜீ & & $r=$ & & & \\
\hline & 亡ا亡 & & 69 & 2 & & \\
\hline ఏ & \begin{tabular}{|l|l|}
\multicolumn{1}{|c|}{$\mid$} \\
\end{tabular} & & ? & $v:$ & 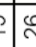 & . \\
\hline 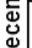 & \begin{tabular}{|l|l|l|l|l|}
3 & \\
\end{tabular} & & +7 & $=\because$ & & \\
\hline & \begin{tabular}{|l|l|} 
\\
\end{tabular} & & $m:$ & 27 & & $\bar{N} \bar{m}$ \\
\hline & \begin{tabular}{|l|l|l|}
${ }^{\prime}$ & \\
\end{tabular} & & \begin{tabular}{c|c}
$N$ & $\sigma$
\end{tabular} & $s$ & & \begin{tabular}{c|c}
$\cdots$ \\
$\cdots$
\end{tabular} \\
\hline & 3 & $\stackrel{\infty}{\rightarrow} \stackrel{\circ}{\circ}$ & g) & is & & הN \\
\hline & \begin{tabular}{|l|l|} 
के \\
\end{tabular} & $m ?$ & 의 7 & $=\overline{5}$ & 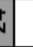 & \\
\hline & 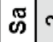 & \begin{tabular}{l|l}
$*$ & 0
\end{tabular} & 015 & & & 品 \\
\hline & \begin{tabular}{|l|l|} 
Lे &
\end{tabular} & \begin{tabular}{l|l}
- & $\infty$ \\
\end{tabular} & $\infty \mid$ & 2 & & S. \\
\hline ๑ & $F$ & & $r$ & 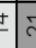 & & No \\
\hline & $3^{0}$ & & 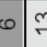 & & & \\
\hline & 3 & & 87 & $v \div$ & 20 & is \\
\hline & $\stackrel{\circ}{\Sigma}$ & & $+F$ & $=$ & & N. \\
\hline & $\left|\begin{array}{l}3 \\
\mid\end{array}\right|$ & 8 & $f|c| c$ & 8 & & \\
\hline & \begin{tabular}{|l|} 
के \\
\end{tabular} & $0 \%$ & 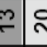 & vi & $\bar{v}$ & \\
\hline & ڤ్ & $\log =$ & $\stackrel{2}{\circ}$ & 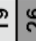 & v & \\
\hline & \begin{tabular}{|l|l|} 
L & \\
\end{tabular} & $\nabla=$ & $\leftarrow \stackrel{\infty}{\sigma}$ & 0 & v. & \\
\hline ळ & 5 & $m: 0$ & $\div 7$ & $=i$ & & $\bar{m}$ \\
\hline 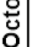 & $\stackrel{0}{3}$ & $\sim \sigma$ & ه & & & p \\
\hline & \begin{tabular}{|l|l} 
& \\
\end{tabular} & $-x^{-}-\infty$ & $\infty$ & $?$ & & N \\
\hline & $\stackrel{0}{\Sigma}$ & & 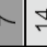 & t5 & & No \\
\hline & $|3|$ & 악 & ซ & $y$ & & g \\
\hline & ज्ञ & $-\infty$ & $\infty$ & & & Nิ \\
\hline & 号 & & $\sqrt{5}$ & \pm & & No \\
\hline & 这 & & 6 . & 2 & $\vec{v} \mid \hat{\sigma}$ & v \\
\hline 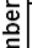 & $F$ & & 67 & $v:$ & $\pi$ & N \\
\hline 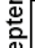 & $\left.\right|_{3} ^{0}$ & & $8:$ & & & \\
\hline & $\Xi$ & & $m \div$ & 27 & & N \\
\hline & $\stackrel{0}{\Sigma}$ & & $\sim \sigma$ & $s$ & & N \\
\hline & \begin{tabular}{|c|c|c|}
3 \\
\multicolumn{1}{|c|}{}
\end{tabular} & ల) & $\stackrel{ल}{ल}$ & & & s. \\
\hline
\end{tabular}

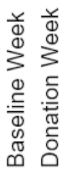




\section{A. 5: Comparison of average tips in Baseline Week between guides}

\begin{tabular}{llllllllllll}
\hline Guide & 1 & 2 & 3 & 4 & 5 & 6 & 7 & 8 & 9 & 10 & 11 \\
\hline 1 & & & & & & & & & & \\
2 & $\mathbf{0 . 0 8 4 1}$ & & & & & & & & & \\
3 & 0.6318 & 0.2879 & & & & & & & & & \\
4 & - & - & & & & & & & & & \\
5 & 0.1003 & 0.7566 & 0.2343 & - & & & & & & & \\
6 & 0.4458 & $\mathbf{0 . 0 7 9 8}$ & 0.4795 & - & $\mathbf{0 . 0 8 8 0}$ & & & & & & \\
7 & $\mathbf{0 . 0 2 5 7}$ & 0.1159 & 0.1441 & - & 0.1658 & $\mathbf{0 . 0 3 3 0}$ & & & & & \\
8 & $\mathbf{0 . 0 0 1 2}$ & $\mathbf{0 . 0 0 0 1}$ & $\mathbf{0 . 0 7 3 6}$ & - & $\mathbf{0 . 0 0 0 3}$ & $\mathbf{0 . 0 2 5 3}$ & $\mathbf{0 . 0 0 0 2}$ & & & & \\
9 & $\mathbf{0 . 0 6 3 7}$ & 0.5643 & 0.1601 & - & 0.6931 & $\mathbf{0 . 0 8 9 4}$ & 0.1501 & $\mathbf{0 . 0 0 0 1}$ & & & \\
10 & 0.6429 & 0.2275 & 0.8883 & - & 0.1781 & 0.2948 & $\mathbf{0 . 0 4 3 4}$ & $\mathbf{0 . 0 0 0 6}$ & 0.1365 & & \\
11 & 0.6229 & 0.2337 & 0.6338 & - & 0.2575 & 0.1859 & $\mathbf{0 . 0 6 4 1}$ & $\mathbf{0 . 0 0 0 6}$ & 0.1575 & 1.0000 & \\
\hline
\end{tabular}

p-value of Wilcoxon rank-sum test indicated

Bold values indicate $\mathrm{p}<0,1$

\section{A. 6: OLS regression on average tips per tour}

\begin{tabular}{|c|c|c|c|c|c|}
\hline VARIABLES & Model I & Model II & Model III & Model IV & Model V \\
\hline $\begin{array}{l}\text { Dummy dona- } \\
\text { tion week } \\
(1=\text { yes })\end{array}$ & $\begin{array}{r}0.482 * * \\
(0.153)\end{array}$ & $\begin{array}{r}0.510^{* *} \\
(0.169)\end{array}$ & $\begin{array}{l}0.482 * * \\
(0.181)\end{array}$ & $\begin{array}{r}0.512 * * * \\
(0.135)\end{array}$ & $\begin{array}{r}0.580^{* * * *} \\
(0.158)\end{array}$ \\
\hline $\begin{array}{l}\text { Dummy Guide } \\
2\end{array}$ & $\begin{array}{c}-0.910^{* * * *} \\
(0.0474)\end{array}$ & $\begin{array}{c}-0.426 * * * \\
(0.0963)\end{array}$ & $\begin{array}{c}-0.626^{* * *} \\
(0.160)\end{array}$ & $\begin{array}{l}0.584 \\
(0.433)\end{array}$ & $\begin{array}{l}0.436 \\
(0.464)\end{array}$ \\
\hline $\begin{array}{l}\text { Dummy Guide } \\
3\end{array}$ & $\begin{array}{c}-0.684 * * * \\
(0.135)\end{array}$ & $\begin{array}{c}-1.164 * * * \\
(0.167)\end{array}$ & $\begin{array}{c}-1.267 * * * \\
(0.151)\end{array}$ & $\begin{array}{c}-0.859 * * \\
(0.265)\end{array}$ & $\begin{array}{c}-1.119 * * \\
(0.396)\end{array}$ \\
\hline $\begin{array}{l}\text { Dummy Guide } \\
5\end{array}$ & $\begin{array}{c}-0.824 * * * \\
(0.0245)\end{array}$ & $\begin{array}{c}-1.023 * * * \\
(0.0581)\end{array}$ & $\begin{array}{c}-0.868 * * * \\
(0.126)\end{array}$ & $\begin{array}{c}-1.370 * * * \\
(0.258)\end{array}$ & $\begin{array}{c}-1.448^{* * * *} \\
(0.254)\end{array}$ \\
\hline $\begin{array}{l}\text { Dummy Guide } \\
6\end{array}$ & $\begin{array}{r}0.352 * * * \\
(0.0235)\end{array}$ & $\begin{array}{r}0.377 * * * \\
(0.0217)\end{array}$ & $\begin{array}{l}0.291 * * * \\
(0.0763)\end{array}$ & $\begin{array}{r}-0.653^{*} \\
(0.338)\end{array}$ & $\begin{array}{r}-0.502 \\
(0.369)\end{array}$ \\
\hline $\begin{array}{l}\text { Dummy Guide } \\
7\end{array}$ & $\begin{array}{c}-1.999 * * * \\
(0.0412)\end{array}$ & $\begin{array}{c}-1.839 * * * \\
(0.0446)\end{array}$ & $\begin{array}{c}-1.735 * * * \\
(0.0996)\end{array}$ & $\begin{array}{c}-1.630 * * * \\
(0.227)\end{array}$ & $\begin{array}{c}-1.638^{* * * *} \\
(0.183)\end{array}$ \\
\hline $\begin{array}{l}\text { Dummy Guide } \\
8\end{array}$ & $\begin{array}{r}3.957 * * * \\
(0.0668)\end{array}$ & $\begin{array}{r}3.708 * * * \\
(0.0987)\end{array}$ & $\begin{array}{r}3.618^{* * * *} \\
(0.0864)\end{array}$ & $\begin{array}{r}4.906^{* * * *} \\
(0.489)\end{array}$ & $\begin{array}{r}4.723 * * * \\
(0.540)\end{array}$ \\
\hline $\begin{array}{l}\text { Dummy Guide } \\
\quad 9\end{array}$ & $\begin{array}{c}-0.664 * * * \\
(0.0396)\end{array}$ & $\begin{array}{c}-1.183 * * * \\
(0.116)\end{array}$ & $\begin{array}{c}-1.177 * * * * \\
(0.117)\end{array}$ & $\begin{array}{c}-1.828 * * * \\
(0.259)\end{array}$ & $\begin{array}{c}-1.910^{* * * *} \\
(0.242)\end{array}$ \\
\hline $\begin{array}{l}\text { Dummy Guide } \\
10\end{array}$ & $\begin{array}{c}-0.187 * * * \\
(0.0109)\end{array}$ & $\begin{array}{r}-0.0364 \\
(0.0301)\end{array}$ & $\begin{array}{l}0.0660 \\
(0.0723)\end{array}$ & $\begin{array}{r}-0.136 \\
(0.163)\end{array}$ & $\begin{array}{r}-0.120 \\
(0.178)\end{array}$ \\
\hline $\begin{array}{l}\text { Dummy Guide } \\
11\end{array}$ & $\begin{array}{r}-0.0108 \\
(0.0210)\end{array}$ & $\begin{array}{c}-0.359^{* * *} \\
(0.0806)\end{array}$ & $\begin{array}{c}-0.257 * * \\
(0.108)\end{array}$ & $\begin{array}{c}-0.602 * * \\
(0.209)\end{array}$ & $\begin{array}{c}-0.632 * * \\
(0.197)\end{array}$ \\
\hline Dummy Sights & & $\begin{array}{r}2.046^{* * * *} \\
(0.409)\end{array}$ & $\begin{array}{r}1.886^{* * * *} \\
(0.431)\end{array}$ & $\begin{array}{r}1.694 * * * \\
(0.445)\end{array}$ & $\begin{array}{l}1.174 \\
\quad(1.002)\end{array}$ \\
\hline
\end{tabular}




\begin{tabular}{|c|c|c|c|c|c|}
\hline VARIABLES & Model I & Model II & Model III & Model IV & Model V \\
\hline $\begin{array}{l}\text { Number of } \\
\text { participants } \\
\text { end-start- } \\
\text { ratio }\end{array}$ & & & $\begin{array}{r}-4.149 \\
(2.908)\end{array}$ & $\begin{array}{r}-4.660^{*} \\
(2.463)\end{array}$ & $\begin{array}{c}-5.558^{* *} \\
(2.398)\end{array}$ \\
\hline Satisfaction & & & & $\begin{array}{l}0.407 \\
\quad(0.237)\end{array}$ & $\begin{array}{l}0.373 \\
(0.257)\end{array}$ \\
\hline Performance & & & & $\begin{array}{l}0.457 \\
\quad(0.252)\end{array}$ & $\begin{array}{l}0.431 \\
\quad(0.252)\end{array}$ \\
\hline $\begin{array}{l}\text { Dummy week- } \\
\text { end }\end{array}$ & & & & & $\begin{array}{l}0.254 \\
\quad(0.390)\end{array}$ \\
\hline $\begin{array}{l}\text { Dummy after- } \\
\text { noon }\end{array}$ & & & & & $\begin{array}{c}-0.859 * * \\
(0.347)\end{array}$ \\
\hline Dummy night & & & & & $\begin{array}{r}-0.958 \\
(0.996)\end{array}$ \\
\hline Temperature & & & & & $\begin{array}{l}0.0354 \\
(0.0279)\end{array}$ \\
\hline Dummy cloudy & & & & & $\begin{array}{l}0.0469 \\
(0.225)\end{array}$ \\
\hline Dummy drizzly & & & & & $\begin{array}{r}-0.163 \\
(0.454)\end{array}$ \\
\hline Dummy rainy & & & & & $\begin{array}{r}0.00860 \\
(0.787)\end{array}$ \\
\hline Dummy storm & & & & & $\begin{array}{r}-1.099 \\
(1.444)\end{array}$ \\
\hline Week & $\begin{array}{l}0.0163 \\
\quad(0.0524)\end{array}$ & $\begin{array}{r}-0.00958 \\
(0.0485)\end{array}$ & $\begin{array}{r}-0.00824 \\
(0.0493)\end{array}$ & $\begin{array}{l}0.0145 \\
\quad(0.0302)\end{array}$ & $\begin{array}{l}0.00941 \\
(0.0188)\end{array}$ \\
\hline Constant & $\begin{array}{r}10.47 * * * \\
(0.310)\end{array}$ & $\begin{array}{r}9.072 * * * \\
(0.419)\end{array}$ & $\begin{array}{r}13.06^{* * * *} \\
(3.042)\end{array}$ & $\begin{array}{l}8.499 * * \\
(3.119)\end{array}$ & $\begin{array}{l}9.969 * * \\
(3.717)\end{array}$ \\
\hline Observations & 272 & 272 & 272 & 272 & 272 \\
\hline R-squared & 0.318 & 0.413 & 0.430 & 0.496 & 0.518 \\
\hline
\end{tabular}

$* * * \mathrm{p}<0.01, * * \mathrm{p}<0.05, * \mathrm{p}<0.1$

Funding Open Access funding enabled and organized by Projekt DEAL.

Open Access This article is licensed under a Creative Commons Attribution 4.0 International License, which permits use, sharing, adaptation, distribution and reproduction in any medium or format, as long as you give appropriate credit to the original author(s) and the source, provide a link to the Creative Commons licence, and indicate if changes were made. The images or other third party material in this article are included in the article's Creative Commons licence, unless indicated otherwise in a credit line to the material. If material is not included in the article's Creative Commons licence and your intended use is not permitted by statutory regulation or exceeds the permitted use, you will need to obtain permission directly from the copyright holder. To view a copy of this licence, visit http://creativecommons.org/licen ses/by/4.0/. 


\section{References}

Alpizar F, Carlsson F, Johansson-Stenman O (2008) Anonymity, reciprocity, and conformity. Evidence from voluntary contributions to a national park in Costa Rica. J Public Econ 92(5-6):1047-1060

Amazon: Amazon smile. https://smile.amazon.com/. Accessed 2 Nov 2020

Andreoni J (1989) Giving with impure altruism. Applications to charity and ricardian equivalence. J Polit Econ 97(6): 1447-1458

Ariely D, Bracha A, Meier S (2009) Doing good or doing well? Image motivation and monetary incentives in behaving prosocially. Am Econ Rev 99(1):544-555

Bénabou R, Tirole J (2004) Willpower and personal rules. J Polit Econ 112(4):848-886

Bigné-Alcañiz E, Currás-Pérez R, Ruiz-Mafé C, Sanz-Blas S (2012) Cause-related marketing influence on consumer responses. The moderating effect of cause-brand fit. J Market Commun 18(4):265-283

Cassar L (2019) Job mission as a substitute for monetary incentives: benefits and limits. Manage Sci 2(65):896-912

Chao Y, Fernandez J, Nahata B (2015) Pay-what-you-want pricing. Can it be profitable?. J Behav Exp Econ 57:176-185

Chéron E, Kohlbacher F, Kusuma K (2012) The effects of brand-cause fit and campaign duration on consumer perception of cause-related marketing in Japan. J Consum Mark 29(5):357-368

Conlin M, Lynn M, O'Donoghue T (2003) The norm of restaurant tipping. J Econ Behav Organ 52(3):297-321

Croson R, Handy F, Shang J (2009) Keeping up with the Joneses. The relationship of perceived descriptive social norms, social information, and charitable giving. Nonprofit Manage Leadersh 19(4):467-489

Crumpler H, Grossman PJ (2008) An experimental test of warm glow giving. J Public Econ 92(5-6):1011-1021

Dahl D, Lavack AM (1995) Cause-related marketing, impact of size of corporate donation and size of cause-related promotion on consumer perceptions and participation.In: 1995 AMA Winter Educators' Conference: Marketing Theory and Applications, vol 6. pp 476-481

Eckel CC, Grossman PJ, Johnston RM (2005) An experimental test of the crowding out hypothesis. J Public Econ 89(8):1543-1560

Eriksson T, Mao L, Villeval MC (2017) Saving face and group identity. Exp Econ 20(3):622-647

Gneezy A, Gneezy U, Nelson LD, Brown A (2010) Shared social responsibility. A field experiment in pay-what-you-want pricing and charitable giving. Science 329(5989):325-327

Gneezy A, Imas A, Brown A, Nelson LD, Norton MI (2012) Paying to be nice. Consistency and costly prosocial behavior. Manage Sci 58(1):179-187

Green T, Peloza J (2011) How does corporate social responsibility create value for consumers? J Consum Mark 28(1):48-56

Harbaugh WT (1998a) The prestige motive for making charitable transfers. Am Econ Rev 88(2):277-282

Harbaugh WT (1998b) What do donations buy? A model of philanthropy based on prestige and warm glow. J Public Econ 67(2):269-284

Holmes JH, Kilbane CJ (1993) Cause-related marketing. Selected effects of price and charitable donations. J Nonprofit Public Sect Market 1(4):67-84

Isaac RM, Lightle J, Norton D (2015) The Pay-What-You-Want Business Model: Warm Glow Revenuesand Endogenous Price Discrimination. J Behav Exp Econ 57:215-223

Jung MH, Nelson LD, Gneezy U, Gneezy A (2017) Signaling virtue. Charitable behavior under consumer elective pricing. Market Sci 36(2):161-323

Kajackaite A, Sliwka D (2017) Social responsibility and incentives in the lab. Why do agents exert more effort when principals donate? J Econ Behav Organ 142:482-493

Kim J-Y, Natter M, Spann M (2009) Pay what you want. A new participative pricing mechanism. J Market 73(1):44-58

Kim J-Y, Natter M, Spann M (2010) Kish. Where customers pay as they wish. Rev Market Sci 8(2):44

Konrath S, Handy F (2018) The development and validation of the motives to donate scale. Nonprofit Volunt Sect Q 47(2):347-375

Krombacher: Nachhaltigkeit Regenwald. https://nachhaltigkeit.krombacher.de/regenwald. Accessed 28 Apr 2020

List JA (2004) Young, selfish and male. Field evidence of social preferences. Econ J 114(492):121-149 
Margolis JD, Elfenbein HA, Walsh JP (2009) Does it pay to be good ... and does it matter? A meta-analysis of the relationship between corporate social and financial performance. Working paper, Harvard University, Cambridge, MA

Martin R, Randal J (2008) How is donation behaviour affected by the donations of others? J Econ Behav Organ 67(1):228-238

Moosmayer DC, Fuljahn A (2010) Consumer perceptions of cause related marketing campaigns. J Consum Mark 27(6):543-549

Nan X, Heo K (2007) Consumer responses to corporate social responsibility (CSR) initiatives. Examining the role of brand-cause fit in cause-related marketing. J Advert 36(2):63-74

Ottoni-Wilhelm M (2017) Altruism and egoism/warm glow in economics and psychology: building a bridge between different experimental approaches. Soc Econ Curr Emerg Ave 79-108

Pampers: Pampers UNICEF Partnership. https://www.pampers.com/en-us/about-us/pampers-unicef-partn ership. Accessed 28 Apr 2020

Park S, Nam S, Lee J (2016) Charitable giving, suggestion, and learning from others. Pay-what-you-want experiments at a coffee shop. J Behav Exp Econ 66:16-22

Pracejus JW, Olsen GD (2004) The role of brand/cause fit in the effectiveness of cause-related marketing campaigns. J Bus Res 57(6):635-640

Reyniers D, Bhalla R (2013) Reluctant altruism and peer pressure in charitable giving. Judgm Decis Mak $8(1): 7-15$

Riener G, Traxler C (2012) Norms, moods, and free lunch. Longitudinal evidence on payments from a pay-what-you-want restaurant. J Soc Econ 41(4):476-483

Robinson SR, Irmak C, Jayachandran S (2012) Choice of cause in cause-related marketing. J Mark 76(4):126-139

Scharf K, Smith S (2016) Relational altruism and giving in social groups. J Public Econ 141:1-10

Shang J, Croson R (2009) A field experiment in charitable contribution. The impact of social information on the voluntary provision of public goods. Econ J 119(540):1422-1439

Sheikh S-U-R, Beise-Zee R (2011) Corporate social responsibility or cause-related marketing? The role of cause specificity of CSR. J Consum Market 28(1):27-39

Smith S, Windmeijer F, Wright E (2015) Peer effects in charitable giving. Evidence from the (running) field. Econ J 125(585):1053-1071

Soetevent AR (2005) Anonymity in giving in a natural context-a field experiment in 30 churches. J Public Econ 89(11-12):2301-2323

Strahilevitz M (1999) The effects of product type and donation magnitude on willingness to pay more for a charity-linked brand. J Consum Psychol 8(3):215-241

Strahilevitz M, Myers JG (1998) Donations to charity as purchase incentives. How well they work may depend on what you are trying to sell. J Consum Res 24(4):434-446

Vishwanathan P, van Oosterhout H, Heugens PPMAR, Duran P, Essen M (2019) Strategic CSR. A concept building meta-analysis. J Manage Stud 57(2):314-350

Wang Q, Dou J, Jia S (2016) A meta-analytic review of corporate social responsibility and corporate financial performance. Bus Soc 55(8):1083-1121

Zogaj A, Tscheulin DK, Lindenmeier J, Olk S (2021) Linking actual self-congruence, ideal self-congruence, and functional congruence to donor loyalty: the moderating role of issue involvement. J Bus Econ 91(3):379-400

Publisher's Note Springer Nature remains neutral with regard to jurisdictional claims in published maps and institutional affiliations. 